報 告

\title{
医療器具予備洗浄方法の検討 一予備洗浄を用手洗浄から浸漬洗浄へ移行するための取り組みと改善したこと一
}

\author{
中家聖子* 平田勝美* 松本芳信* \\ 松島由美* 立田浩*
}

\section{1. はじめに}

手術室や病棟からの污染した器具類は, 洗浄 室に搬入され使用可能な状態に洗浄・消毒・滅 菌される．機械洗浄前の予備洗浄として用手洗 浄と浸漬洗浄がある. 用手によるブラッシング 洗浄は, 目に見える污染物を目視で確認しなが ら洗浄できる。しかし危険な器具を取り扱うた め, 作業者の危険性は十分考慮しなければなら ない. 病棟からの污染器具は, 使用後すぐ洗浄 できない場合がある。週末などでは污染器具が 洗浄されるまでに, 使用後数時間から数日経過 している場合もあり, 污染物の固着の程度に よっては, ブラッシング作業が久かせない.し かし職業感染の面からも，できるだけ用手洗浄 を省き次の工程に進みたい。一方, 浸漬洗浄は, 酵素系の浸漬洗浄剤に器具を浸漬させることに より污染物を除去する。 そのため作業者の危険 性は低い。しかし污染物が物理的に除去できな いため残存する可能性がある。酵素系洗浄剤を 用いた浸漬洗浄が，ブラッシングによる用手洗 浄の代わりになりうるかを検証した。

\section{2. 目 的}

予備洗浄過程において, 用手洗浄を廃止でき るかどうかを検証する。

(1)浸漬洗浄のみで用手洗浄と同等の効果が あるかどうか.

(2)当院の浸漬洗浄の方法で, 洗浄効果が十分

* 社会福祉法人 恩賜財団 大阪府済生会茨木医療 福祉セン夕一 大阪府済生会茨木病院 感染管理室
発揮できる条件（濃度，時間，温度，設置 方法）であるか.

(3)循環式恒温槽による浸漬洗浄において, 浸 漬洗浄前後での洗浄効果の評価をする.

\section{3. 方 法}

対象器具としては実際に使用した剪刃などの はさみ類．浸漬液は蛋白分解酵素配合の中性洗 剂（SCLEAN EW）を使用。濃度，浸漬時間， 浸漬温度については，実際に検証する前に実態 調査した。

当院では病棟から搬入された污染器具は, 污 染してから数時間経過し乾燥していることがあ るため, ブラシを使用した用手洗浄をおこなっ た後, ウォッシャーディスインフェクター（以下 WD）（Beli Med WD250）で機械洗浄をする. 用手洗浄は，毎日ほぼ同じ担当者がおこない， 経験年数は 5 から 6 年である。用具は，主にダ ブルヘッドブラシ 長さ $17.5 \mathrm{~cm}$ のものを使用 し，蛋白分解酵素が配合された中性洗剤 （SCLEAN EW）を水道水ですすぎながら, 目 視で污れがなくなるまでブラシを用いて洗浄し ている.

手術室からの污染器具は污染後数時間以内 で洗浄室に搬入され，血液や体液などの污染物 の乾燥や付着が少ないため, 器具は浸漬液に浸 漬しその後 WD で機械洗浄する。浸漬洗浄は 通常は手術室の污染器具を対象としており, 使 用後洗浄室に運ばれてから, 容器に規定量（浸 漬剂 $150 \mathrm{ml}$ と水 $30 \mathrm{~L})$, 規定温度 $\left(40^{\circ} \mathrm{C}\right)$ で準 備した溶液に 30 分以上浸漬する。使用する容 器は, プラスチック製の容器（図 1 ）である. 


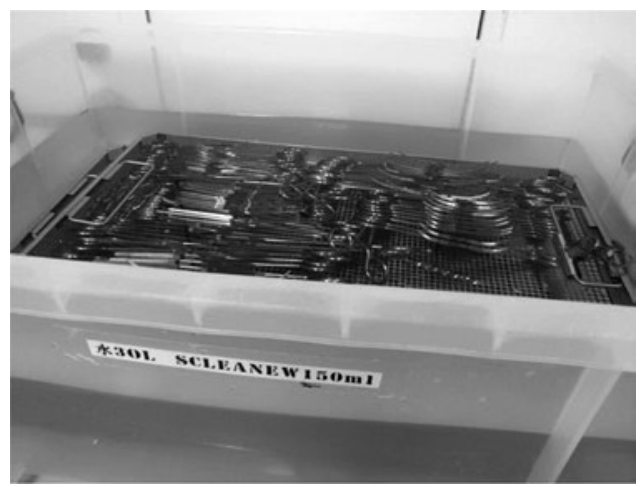

図 1 浸漬消毒容器

今回は病棟からの, 血液や体液などの污染物 が付着したハサミについて用手洗浄のみで処理 した器具と浸漬洗浄のみで処理した器具で残存 污染を検査した。

残存污染検查として, 用手洗浄と浸漬洗浄前 後で 3 MTM クリーントレース TMATP 測定 機器ルミノメータ NGI@（以下ATP 測定器) によるふき取り検査と, 蛋白質色素染色液アミ ドブラック 10B（以下アミドブラック）による 污染の目視確認をおこなった。評価部位は, ふ き取り検査も，アミドブラックの塗布もはさみ の関節部と先端で測定した。また循環式恒温槽 での浸漬洗浄をおこない, 浸漬洗浄前後の洗浄 評価をした。

\section{4. 結 果 (表 1 )}

浸漬洗浄時の浸漬濃度は $0.5 \%$, 浸漬温度は $29^{\circ} \mathrm{C}$ ，浸漬時間は 30 分から 60 分であった。

(1)用手洗浄での評価

洗浄前の ATP ふき取り検査では，120,000

\section{表 1 結果（すべて器具は剪刃類）}

\begin{tabular}{|c|c|c|c|}
\hline & $\begin{array}{c}\text { 用手洗浄のみ } \\
\text { (ATP) }\end{array}$ & $\begin{array}{c}\text { 浸漬洗浄のみ } \\
\text { (ATP) }\end{array}$ & $\begin{array}{l}\text { 浸漬洗浄のみ } \\
\text { (アミドブラック) }\end{array}$ \\
\hline $\begin{array}{l}\text { 洗 } \\
\text { 浄 } \\
\text { 前 }\end{array}$ & $\begin{array}{c}120,000 \sim 300,000 \\
\text { (Relative Light Unit,RLU) }\end{array}$ & $\begin{array}{c}300,000 \sim 320,000 \\
\text { (Relative Light Unit,RLU) }\end{array}$ & 付着 \\
\hline $\begin{array}{l}\text { 洗 } \\
\text { 浄 } \\
\text { 後 }\end{array}$ & $\begin{array}{c}200 \sim 650 \\
\text { (Relative Light Unit,RLU) }\end{array}$ & $\begin{array}{c}70 \sim 80 \\
\text { (Relative Light Unit,RLU) }\end{array}$ & 付着 \\
\hline $\begin{array}{l}\text { W } \\
D \\
\text { 後 }\end{array}$ & $\underset{\text { (Relative Light Unit,RLU) }}{8 \sim 60}$ & $\begin{array}{c}\text { 10以下 } \\
\text { (Relative Light Unit,RLU) }\end{array}$ & なし \\
\hline
\end{tabular}

丸用手洗浄の場合, アミドブラックで可視化された污染を意図 的に洗浄するので評価できず.
～300,000 (Relative Light Unit.RLU) であっ た. 洗浄後は, 200〜650 (Relative Light Unit. RLU) へ数值が低下した.

(2)浸漬洗浄での評価

洗浄前の ATP ふき取り検査では, 300,000 〜 320,000 (Relative Light Unit.RLU) であっ た. 洗浄後は, $70 \sim 80$ (Relative Light Unit. RLU) へ数值が低下した.

(3)目視での污れの確認

ほぼ污染は洗浄されていたが浸漬洗浄後に, 一部の剪刃の関節部にアミドブラックの残存 を認めた. またアミドブラックでの検査は, 可 視化された污染を意図的に洗浄するため, 用 手洗浄での洗浄評価はできなかった（図 2 ). (4)用手, 浸漬洗浄後再度ウオッシャーディス インフェクターで污れを評価

用手洗浄では, 8〜60 (Relative Light Unit. RLU), 浸漬洗浄では, 10 (Relative Light Unit. RLU）以下となり, WDにより污染物は除 去されていた。

(5)循環式恒温槽を使用しての洗浄評価 循環式恒温槽の浸漬洗浄温度を 40 度に設 定, 浸漬時間は 30 分, 浸漬濃度は $0.5 \%$ とし, アミドブラックを用いて評価をおこなった。 測定部位は関節部と先端とした。

その結果，ほぼ浸漬洗浄により污染は洗浄 されていたが一部の剪刃の関節部にアミド ブラックの残存を認めた.

\section{5. 考察}

酵素系の洗浄剤は, 酵素により蛋白污れを分 解し水への溶解・分散を促進している ${ }^{1)}$. 酵素 系洗浄剂の洗浄効果には, 濃度, 時間, 温度が 関与する。酵素は一般に $40^{\circ} \mathrm{C}$ から $50^{\circ} \mathrm{C}$ で最も 活発に作用する. $20^{\circ} \mathrm{C}$ 以下では作用が非常に弱 くなる ${ }^{2)}$. 当院の場合, 洗浄液を朝 9 時に $40^{\circ} \mathrm{C}$ で準備するが, 保温機能が備わっていないプラ スチック容器では, 時間の経過とともに温度が 低下していた。酵素洗浄剤による浸漬洗浄は浸 漬温度が, $40^{\circ} \mathrm{C} て ゙ は 30$ 分間の浸漬でよく洗浄 されるが, $30^{\circ} \mathrm{C} て ゙ は 40$ 分間必要である ${ }^{1)}$ 。恒 温機能のない浸漬洗浄容器の場合, 洗浄液の交 換頻度を多くする，または浸漬液を保温するた 


\begin{tabular}{|c|c|c|}
\hline \multicolumn{2}{|c|}{ 目視評価(アミドブラック) } & $\begin{array}{c}\text { ウォッシャー } \\
\text { ディスインフェクター }\end{array}$ \\
\hline 浸漬洗浄前 & 浸漬洗浄後 & 洗浄後 \\
\hline 污染あり & 污染残留あり & 污染なし \\
\hline
\end{tabular}

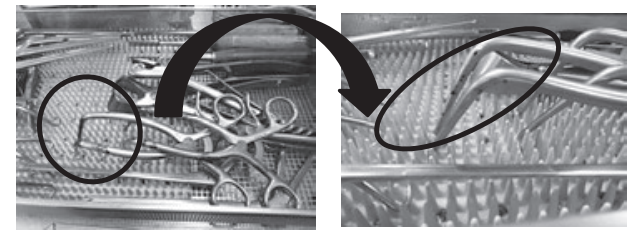

アミドブラックの残留
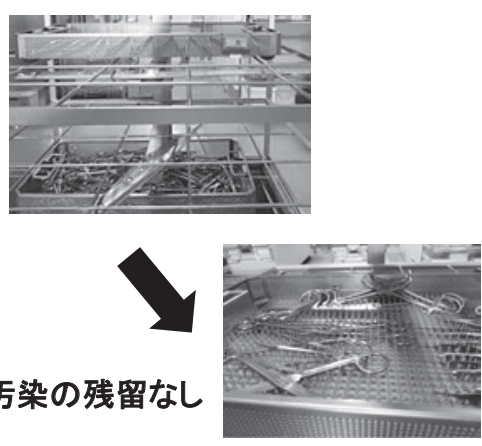

図2 浸漬洗浄後の器具の確認

めに, 容器外側を保温シートで覆うなどの対策 などが必要であると考える. $40^{\circ} \mathrm{C}$ に浸漬温度を 保つことができれば，浸漬時間を短縮すること が可能である.

循環式恒温槽を使用した浸漬洗浄では, 洗浄 液は攪拌され, 新しい洗浄液が絶えず器具に接 触する。洗浄液を攪拌する(動かす)ことによっ て温度のむらをなくし, 常に温度を一定に保つ ようにしている，浸漬洗浄における恒温槽の使 用は温度管理をおこなうことに加え, 洗浄効率 を上げるという観点から非常に有用である ${ }^{3)}$. 循環式恒温槽の浸漬洗浄条件を整えれば，すべ ての污染物は除去されると予測し検討したが, 一部の剪刃の関節部にはやはりアミドブラック の残存を認めた。

浸漬洗浄前の器具の污れを確認したところ, 剪刃やはさみなどの器具に付着していた污染物 は主に血液や蛋白質で病棟により使用され搬入 されるまで時間が経過した器具であった。 その ため, 污染物の固着が強く, 洗浄効果を低下さ せたと考えられる. 使用後は, 速やかに污染物 を洗い落すか, 蛋白凝固防止スプレー (SCLERN Pre）により乾燥を防止する必要がある.

浸漬洗浄は, ブラッシングによる用手洗浄や
WD などのように物理的に外から力を加えて水 圧により污染物を除去するものではない. あく までも洗浄液の接触により污れを洗浄液に溶解 させる. そのため, 污染の強い器具に関しては, 浸漬洗浄だけで洗浄することは, 困難だと考え る. 病棟での一次洗浄の廃止することが推奨さ れており, それに伴い, 使用した器具は凝固防 止スプレー（SCLERN Pre）を使用し血液や蛋 白の乾燥を防止する. 凝固防止スプレーは污染 物の固着を防止する役割を果たすが，付着した 血液等の乾燥を防ぐことも洗浄力を高めること になる ${ }^{1)}$ 。また細かい器具は凝固防止スプレー を十分に使用し, 浸漬洗浄をおこなう。しかし, 眼科器具などは, 中毒性前眼部症候群 (toxican teriorsegmentsyndrome,TASS ${ }^{4)}$ を考慮し，さ らに用手洗浄によるすすぎ作業の追加が必要で ある。

このような洗浄前の処置をおこない, 至適条 件で浸漬洗浄をおこなっても, 用手洗浄を全く 廃止することは困難であり, 用手, 浸漬洗浄の 方法を組み合わせることが必要である。作業者 への曝露の観点からは, 浸漬洗浄前の予備洗浄 をできるだけ省略できるように污染物の程度と質 に合わせて業務を検討することが重要である. 
(94) 医機学 Vol.88, No.4 (2018)

浸漬洗浄のみでは WD 後には污染の残存は 認めなかったものの, 今回の検討では, 用手洗浄 に比べて洗浄度は明らかに劣ることが判明した。

\section{6. まとめ}

ブラッシングによる用手洗浄を廃止するため の取り組みをおこなった。浸漬洗浄のみでは, 污染物は完全に除去できなかった。污染の質や 程度により用手, 浸漬洗浄の方法を組み合わせ るなど, 洗浄方法の選択が必要である.

\section{文 献}

1 ）大久保憲. EBMに基づいて速効解決 洗浄 . 消毒・滅菌のポイント209. インフェクション コントロールMCメディカ出版. 2004.

2 ) 島崎豊, 吉田葉子. 医療器材の洗浄から滅菌まで. ヴァンメディカル. 2013.

3) 川原昌子, 谷野雅昭. 浸漬洗浄に打ける洗浄液攪 拌の効果. 医機学 Vol.79, No.7. P.564-565(2009).

4) Mamalis N.Edelhauser HF.DC.et al.Toxic anterior segment syndrome Cataract Refract Surg. 2006,32,P.324-333. 